\title{
Type 1 Papillary Renal Cell Carcinoma
}

National Cancer Institute

\section{Source}

National Cancer Institute. Type 1 Papillary Renal Cell Carcinoma. NCI Thesaurus. Code C27886.

A papillary renal cell carcinoma characterized by the presence of papillae covered by small cells with scant amount of cytoplasm. The cells are arranged in a single layer on the basement membrane of the papillae. 